\title{
Narrativa, testemunho E Delicadeza: \\ a Casa de Memória e Cultura do Córrego dos Januários
}

Denise Sampaio Gusmão

Esta pesquisa intervenção relata o percurso da re-construção coletiva da memória do Córrego dos Januários, pequeno povoado situado na região leste de Minas Gerais, no município de Inhapim. Tal processo envolveu diferentes autores e atores que se articularam com os habitantes desta localidade com o objetivo de conceber um espaço onde as coisas, as imagens, as palavras, os pensamentos pudessem encontrar uma morada, um espaço onde as materialidades criadas pelos homens conquistassem um lugar no futuro. Assim, a Casa de Memória e Cultura do Córrego dos Januários foi idealizada, concebida e finalmente inaugurada em agosto de 2008. Vale destacar que este é um texto polifônico, no qual sem dúvida coexistem múltiplas vozes, que dão contorno e profundidade às concepções de história, narrativa, memória, estética da delicadeza e testemunho.

Dentre os principais autores destacamos Walter Benjamin, Maurice Halbwachs, Mikhail Bakhtin, Hannah Arendt, Michel de Certeau, Michael Pollak, Ecléa Bosi, Paul Thompson, Jeanne Marie Gagnebin, Marcio Selligman-Silva, Mario de Souza Chagas, entre outros, além das muitas vozes do Córrego dos Januários que participaram intensamente na construção deste mosaico de memórias. Durante este percurso de memória, nos deparamos com a origem etimológica do nome Januário: o deus romano Janus. A imagem alegórica de Janus Bifronte nos conduziu por um rio de memória mais profundo e com ele reafirmamos nossa tese de que esta Casa de Memória e Cultura se dá no entrecruzamento dos tempos e que nosso maior esforço teórico metodológico foi torná-la, junto com os "Januários”, um espaço onde o apelo à felicidade do presente se faça ouvir.

\section{BANCA:}

Solange Jobim e Souza (Orientadora)

Márcio Orlando Seligmann-Silva

Mário de Souza Chagas

Monique Rose Aimée Augras

Sonia Kramer

Data de defesa: 01/10/2009 